\title{
Proposal of Viridibacillus gen. nov. and reclassification of Bacillus arvi, Bacillus arenosi and Bacillus neidei as Viridibacillus arvi gen. nov., comb. nov., Viridibacillus arenosi comb. nov. and Viridibacillus neidei comb. nov.
}

Correspondence Richard A. Albert richard.albert@marquette.edu
Richard A. Albert, ${ }^{1} \dagger$ Julieta Archambault, ${ }^{1} \ddagger$ Melissa Lempa, ${ }^{1}$ Beth Hurst, ${ }^{1}$ Christine Richardson, ${ }^{1} \ddagger$ Stephanie Gruenloh, ${ }^{1,2}$ Metin Duran, ${ }^{3}$ Hanna Lucia Worliczek, ${ }^{4}$ Birgit E. Huber, ${ }^{4}$ Ramon Rosselló-Mora, ${ }^{5}$ Peter Schumann ${ }^{6}$ and Hans-Jürgen Busse ${ }^{4}$

\footnotetext{
${ }^{1}$ Semco BioScience, 630 East Keefe, Milwaukee, WI 53212, USA

${ }^{2}$ Medical College, University of Wisconsin, Milwaukee, WI, USA

${ }^{3}$ Department of Civil and Environmental Engineering, Villanova University, Villanova, PA, USA

${ }^{4}$ Institut für Bakteriologie, Mykrologie und Hygiene, Veterinärmedizinische Universität Wien, Veterinärplatz 1, A-1210 Vienna, Austria

${ }^{5}$ Grup de Microbiologia Marina, Institut Mediterrani d'Estudis Avançats, E-07190 Esporles, Mallorca, Spain

${ }^{6} \mathrm{DSMZ}$ - Deutsche Sammlung von Mikroorganismen und Zellkulturen GmbH, D-38124 Braunschweig, Germany
}

A polyphasic study was undertaken to clarify the taxonomic position of endospore-forming strains 433-D9, 433-E17 and 121-X1. BOX-PCR-generated fingerprints indicated that they may be members of a single species. 16S rRNA gene sequence similarity demonstrated that a representative of this group, 433-D9, is affiliated closely with Bacillus arvi DSM $16317^{\top}(100 \%)$, Bacillus arenosi DSM $16319^{\top}(99.8 \%)$ and Bacillus neidei NRRL BD-87 ${ }^{\top}$ (97.1\%). Sequence similarities revealed Bacillus pycnus NRRL NRS- $1691^{\top}$ and several Kurthia species as the next nearest relatives. DNA-DNA hybridization results showed that strain 433-D9 is a member of B. arvi. Detection of L-Lys-D-Asp-based peptidoglycan in strain 433-D9, B. arvi DSM $16317^{\top}$ and $B$. arenosi DSM $16319^{\top}$ was in agreement with their close relationship, but differentiated these strains from B. neidei NRRL BD-87 ${ }^{\top}$ and $B$. pycnus NRRL NRS $-1691^{\top}$, for which L-Lys-D-Glu was reported. A similar quinone system was detected in strains 433-D9, 433-E17, 121-X1, B. arvi DSM $16317^{\top}$, B. arenosi DSM $16319^{\top}$ and B. neidei NRRL BD-87 ${ }^{\top}$. This system, unusual for bacilli, consisted of the major compound menaquinone MK-8 (69-80\%) and moderate amounts of MK-7 (19-30\%). This observation was in contrast to the predominance of MK-7 of the closest relative $B$. pycnus NRRL NRS- $1691^{\top}$, as also reported for representatives of the closely related non-endospore-forming genus Kurthia. Strains 433-D9, B. arvi DSM $16317^{\top}$ and $B$. arenosi DSM $16319^{\top}$ exhibited homogeneous and discriminative polar lipid profiles and fatty acid profiles consisting of major acids $i-C_{15: 0}$ and ai- $C_{15: 0}$ and moderate amounts of $i-C_{17: 1} \omega 10 c$ and $i-C_{17: 1} l / a i-C_{17: 1} B$ that discriminated them from closely related strains such as B. neidei NRRL BD- $87^{\top}$. On the basis of clear-cut discriminative chemotaxonomic markers, we

tPresent address: Water Quality Center, Marquette University, Civil and Environmental Engineering, PO Box 1881, Milwaukee, WI, USA.

‡Present address: Genesis Technologies International, 696 Winer Industrial Way, Lawrenceville, GA, USA.

The GenBank/EMBL/DDBJ accession number for the 16S rRNA gene sequence of strain 433-D9 is AY266991.

BOX-PCR profiles, phase-contrast micrographs of cells of strain 433-D9 and photographs of growth of strain 433-D9 are available as supplementary material with the online version of this paper. 
propose strains 433-D9, 433-E17 and 121-X1, B. arvi DSM $16317^{\top}$, B. arenosi DSM $16319^{\top}$ and $B$. neidei NRRL BD- $87^{\top}$ to be reclassified within a separate genus. For this new taxon, we propose the name Viridibacillus gen. nov., and we propose the reclassification of Bacillus arvi, Bacillus arenosi and Bacillus neidei as Viridibacillus arvi gen. nov., comb. nov. (the type species of Viridibacillus, with the type strain DSM $16317^{\top}=$ LMG $22165^{\top}$ ), Viridibacillus arenosi comb. nov. (type strain DSM $16319^{\top}=$ LMG $22166^{\top}$ ) and Viridibacillus neidei comb. nov. (type strain NRRL BD-87 ${ }^{\top}=$ DSM $15031^{\top}=$ JCM $11077^{\top}$ ).

Since the publication of Ash et al. (1991), in which the subdivision of the genus Bacillus into at least five groups was demonstrated, it has been split into numerous newly described genera (Ash et al., 1993; Fortina et al., 2001; Heyndrickx et al., 1998; Ishikawa et al., 2002; Lu et al., 2001; Nakamura et al., 2004; Nazina et al., 2001; Schlesner et al., 2001; Shida et al., 1996; Spring et al., 1996; Wainø et al., 1999; Wisotzkey et al., 1992; Yoon et al., 2001c). Many of these reclassifications are well supported by relatively conserved phenotypic traits such as quinone system, peptidoglycan composition and polar lipid and/or cellular fatty acid profiles. In conclusion, the genus Bacillus sensu stricto should be restricted to species that share high $16 \mathrm{~S}$ rRNA gene sequence similarities with the type species of the genus, Bacillus subtilis, and its chemotaxonomic traits. The latter would include the presence of menaquinone MK-7, a peptidoglycan with the characteristic diamino acid meso-diaminopimelic acid, a polar lipid profile with the major to moderate compounds diphosphatidylglycerol, phosphatidylglycerol, phosphatidylethanolamine, an unknown aminophospholipid and gentiobiosyldiacylglycerol and a cellular fatty acid profile in which branched fatty acids predominate (Kämpfer et al., 2006).

The recently described species Bacillus pycnus, Bacillus neidei, Bacillus arvi and Bacillus arenosi (Nakamura et al., 2002; Heyrman et al., 2005) exhibit a high degree of $16 \mathrm{~S}$ rRNA gene sequence similarity to species of the genus Kurthia (a genus lacking endospore formation), ranging from 95.1 to $96.6 \%$. In conclusion, they can be considered as members of Bacillus rRNA group 2 (Ash et al., 1991; Farrow et al., 1994). Furthermore, B. pycnus and B. neidei exhibit L-Lys-D-Glu in the cell-wall peptidoglycan (Nakamura et al., 2002), which corresponds to peptidoglycan types A4 $\alpha$ (Schleifer \& Kandler, 1972) and A11.33 (http://www.dsmz.de/species/murein.htm). This trait is in agreement with the characteristics of Bacillus rRNA group 2. The species B. arvi, B. arenosi and B. neidei share among each other sequence similarities in the range 97.1-99.8\%, whereas $B$. pycnus appears to be more distantly related, exhibiting $95.2-96.7 \%$ similarity to the other three species. These values indicate almost the same degree of relatedness for $B$. pycnus and for representatives of the genus Kurthia to the group consisting of B. arvi, B. arenosi and B. neidei and hence the latter group might be considered members of a new genus. Based upon sequence similarities, B. pycnus can be considered as a representative of another genus.
The present study was undertaken to classify strains 433 D9, 121-X1 and 433-E17 which, in the course of this study, were affiliated to $B$. arvi. The three strains were isolated from organic-matter-rich samples from a sphagnum bog, river sediment and forest soil, respectively, in south-eastern Wisconsin using methods described previously (Albert et al., 2005). After heat shocking, samples were subcultured in plate count broth (PCB; Difco) and incubated aerobically at $10{ }^{\circ} \mathrm{C}$. Periodically, samples were streaked onto plate count agar (PCA; Difco) and incubated at $10{ }^{\circ} \mathrm{C}$.

In order to provide evidence that strains 433-D9, 121-X1 and 433-E17 may belong to a single species, they were subjected to BOX-PCR (Wieser \& Busse, 2000). All three strains exhibited a product at approximately $800 \mathrm{bp}$ (see Supplementary Fig. S1 in IJSEM Online), suggesting that they are strains of the same species. Strains $121-\mathrm{X} 1$ and 433-E17 showed identical genomic fingerprints, indicating that they might be clonally related. A representative of this group, strain 433-D9, was subjected to 16S rRNA gene sequence analysis as reported previously (Albert et al., 2005).

Sequence comparisons (Pearson \& Lipman, 1988) of its $16 \mathrm{~S}$ rRNA-encoding gene showed that strain 433-D9 shared highest sequence identities with $B$. arvi DSM $16317^{\mathrm{T}}(100 \%)$, B. arenosi DSM $16319^{\mathrm{T}}(99.8 \%)$ and $B$. neidei NRRL BD- $87^{\mathrm{T}}(97.1 \%)$ and $96.7 \%$ similarity with $B$. pycnus NRRL NRS-1691 ${ }^{\mathrm{T}}$. Kurthia species (95.7-96.5\% similarity), Sporosarcina macmurdoensis CMS $21 \mathrm{w}^{\mathrm{T}}$ (95.7\%) and Bacillus sphaericus DSM $28^{\mathrm{T}}(95.0 \%)$ were identified as moderately related. Phylogenetic analyses (Fig. 1) were performed by the use of the program ARB (Ludwig et al., 2004) as indicated in the figure legend. The results supported the observed relationships. DNA-DNA hybridizations were carried out with strain 433-D9, B. arvi DSM $16317^{\mathrm{T}}$ and B. arenosi DSM $16319^{\mathrm{T}}$, following the method described by Ziemke et al. (1998). DNA-DNA relatedness of $88 \%$ (reverse $80 \%$ ) with B. arvi DSM $16317^{\mathrm{T}}$ and $55 \%$ with $B$. arenosi DSM $16319^{\mathrm{T}}$ identified isolate 433-D9 as a strain of the species B. arvi. Strains 121$\mathrm{X} 1$ and 433-E17 can be also considered to be strains of $B$. arvi, because they share with strain 433-D9 similar BOX fingerprints.

In order to compare strains 433-D9, 121-X1 and 433-E17 with B. arvi DSM $16317^{\mathrm{T}}$, B. arenosi DSM $16319^{\mathrm{T}}$, B. neidei NRRL BD- $87^{\mathrm{T}}$ and B. pycnus NRRL NRS- $1691^{\mathrm{T}}$, this set of 


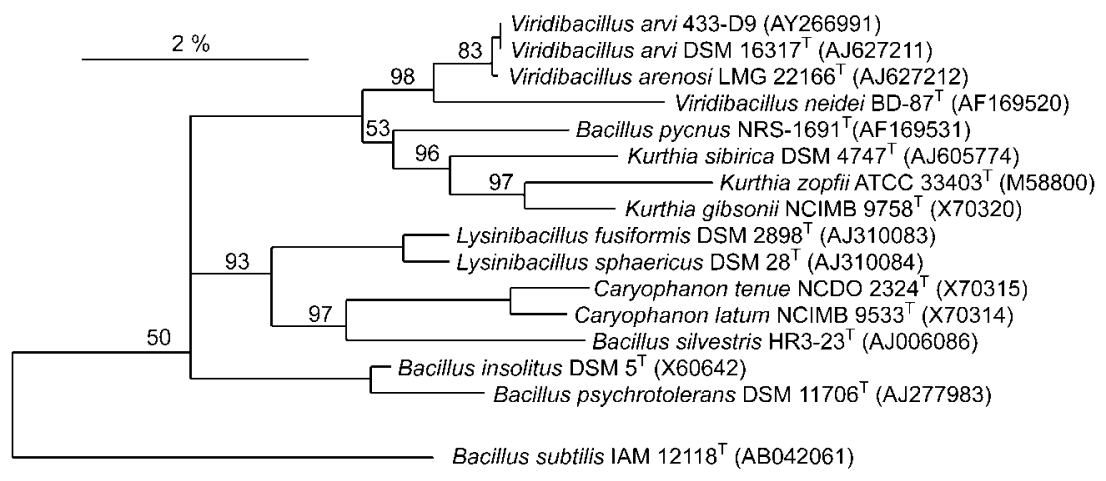

Fig. 1. Phylogenetic reconstruction based on a neighbour-joining algorithm showing the affiliation of strain 433-D9, Viridibacillus (Bacillus) arvi DSM $16317^{\top}$, Viridibacillus (Bacillus) arenosi LMG 22166 ${ }^{\top}$ and Viridibacillus (Bacillus) neidei NRRL BD-87 ${ }^{\top}$ with their closest relatives. The tree is a result of a consensus topology obtained after the evaluation of multiple trees by using neighbour-joining, maximum-parsimony and maximum-likelihood algorithms with different datasets and masks as implemented in the ARB program. Multifurcations show those branching orders that could not be resolved unambiguously. Bootstrap values are based on evaluation of 1000 trees by the neighbourjoining method with the same dataset as shown in the tree and indicate the percentage of reconstructions where a given branch appeared consistently. Bar, 2\% sequence divergence.

strains was subjected to physiological and biochemical characterization and analyses of their cellular fatty acids, polar lipids, cell-wall composition and respiratory quinone systems. Respiratory quinones, cell-wall composition and polar lipids had not been reported previously for $B$. arvi or B. arenosi (Heyrman et al., 2005), while Nakamura et al. (2002) did not report the polar lipid profiles or quinone system of B. neidei and B. pycnus.

The physiological and biochemical characterizations reported in Table 1 as part of this investigation were performed as follows. All tests were performed at $25{ }^{\circ} \mathrm{C}$, except growth temperature range, using $24 \mathrm{~h}$-old cultures grown on PCA. Indole production, lysine decarboxylase, casein and starch hydrolysis, motility testing, catalase activity, oxidase test and Gram staining were assessed using standard procedures (Smibert \& Krieg, 1994).
Gelatin hydrolysis was determined by inoculating tubes of $12 \%$ nutrient gelatin (Difco) and incubating with shaking aeration for 7 days. Temperature tolerance was determined by visual examination for growth on PCA plates. Prior to inoculation, the plates were incubated at the test temperature for $24 \mathrm{~h}$. After inoculation, plates were incubated for 2-7 days. Anaerobic growth was determined by monitoring for growth visually in thioglycolate broth supplemented with glucose (Difco). After inoculation, the tubes were placed in the anaerobe jars and anaerobic conditions were generated using $\mathrm{H}_{2}$ and $\mathrm{CO}_{2}$ GasPaks $(\mathrm{BBL})$. Ten days later, the tubes were removed from the anaerobic conditions and examined visually for growth. Turbidity was used to indicate growth. All tubes were streaked onto PCA to determine the identity of the bacterium present. Growth at $\mathrm{NaCl}$ concentrations of 2, 5,7 and $10 \%(\mathrm{w} / \mathrm{w})$ was determined by inoculating tubes

Table 1. Differentiating characteristics between B. neidei, B. arvi, B. arenosi and B. pycnus

Strains: 1, B. arvi DSM $16317^{\mathrm{T}}, 433-\mathrm{D} 9,121-\mathrm{X} 1$ and 433-E17; 2, B. neidei NRRL BD-87 ${ }^{\mathrm{T}}$; 3, B. arenosi DSM $16319^{\mathrm{T}}$; 4. B. pycnus NRRL NRS- $1691^{\mathrm{T}}$. All data were obtained in this study. All strains are motile and positive for catalase and growth in $2 \% \mathrm{NaCl}$ and negative for oxidase, growth in $7 \% \mathrm{NaCl}$, starch and casein hydrolysis, indole production, the Voges-Proskauer test, citrate utilization and acid production from Dglucose, D-mannitol, D-xylose, D-lactose, glycerol, sucrose, D-ribose, D-mannose, D-galactose, L-arabinose and D-cellobiose.

\begin{tabular}{|c|c|c|c|c|}
\hline Character & 1 & 2 & 3 & 4 \\
\hline Temperature range $\left({ }^{\circ} \mathrm{C}\right)$ & $5-40$ & $5-45$ & $5-37$ & $10-45$ \\
\hline Growth in $5 \% \mathrm{NaCl}$ & - & + & - & - \\
\hline Gelatin hydrolysis & + & + & + & - \\
\hline Acid production from $\mathrm{D}$-fructose & + & + & - & - \\
\hline Cell-wall type & L-Lys-D-Asp & L-Lys-D-Glu & L-Lys-D-Asp & L-Lys-D-Glu \\
\hline
\end{tabular}


containing $10 \mathrm{ml} \mathrm{PCB}$ at the defined $\mathrm{NaCl}$ concentrations. After inoculation, the tubes were incubated with shaking aeration for 2-7 days. Appearance of turbidity was used to indicate growth. All tubes were streaked on PCA to determine the identity of the bacterium present. Citrate utilization, the Voges-Proskauer test and acid production from D-glucose, D-mannitol, D-xylose, D-lactose, glycerol, sucrose, D-ribose, D-mannose, D-galactose, fructose, Larabinose and D-cellobiose were assessed using the methods described by Gordon et al. (1973). Tubes were incubated for up to 7 days.

Results for the physiological and biochemical characterizations performed as part of this study are similar to those reported previously (Nakamura et al., 2002; Heyrman et al., 2005) except for the following. This study found that all strains including the type strains of $B$. arvi, B. neidei and $B$. arenosi were able to liquefy gelatin. $B$. neidei NRRL BD $-87^{\mathrm{T}}$ was found to produce acid from fructose and grow weakly anaerobically. Differences are probably due to differences in test methods.

Colonies of isolates 433-D9, 433-E17 and 121-X1 developed irregular to lobate edges with a slight greenish tint when grown on PCA at $25{ }^{\circ} \mathrm{C}$ for $48 \mathrm{~h}$. With longer incubation, the greenish colour became more obvious. Employing the same conditions, B. arvi DSM $16317^{\mathrm{T}}, B$. arenosi DSM $16319^{\mathrm{T}}$, B. neidei NRRL BD- $87^{\mathrm{T}}$ and $B$. pycnus NRRL NRS- $1691^{\mathrm{T}}$ did not show the green colour. The relationship between the appearance of the green pigment and sporulation was further examined by using different growth media. The media used were PCA, TSA and R2A (all from Difco), which represent a range of nutrient contents. All strains were grown aerobically at $25^{\circ} \mathrm{C}$. Colour development was determined by examining the colony colour visually and using a sterile cotton swab to remove cells from the heavy growth area of the plate and examining the colour on the swab visually. The sporulation process was monitored by using microscopic observations of wet mounts from the heavy streak areas.

On PCA after 48-72 h of growth, endospores were observed for all strains, although only strains 433-D9, 433-E17 and 121-X1 displayed the development of the green pigment (Supplementary Fig. S2). After $48 \mathrm{~h}$ of growth on PCA, strains 433-D9, 433-E17 and 121-X1 displayed the development of the green pigment, when approximately $60-70 \%$ of the cells contained endospores, with a few free spores present. By $72 \mathrm{~h}$, the green pigment was obvious, with an increase in the number of free spores. Growth of all strains on TSA was excellent. However, sporulation for all strains was poor. Under these conditions, all strains, including strains 433-D9, 433-E17 and 121-X1, did not develop the green colour. After $24 \mathrm{~h}$ of growth on R2A, all strains grew readily and developed endospores $(>95 \%)$ but did not display the green colour. However, after $48 \mathrm{~h}$ of growth, strains 433-D9, 433-E17, 121-X1, B. arvi DSM $16317^{\mathrm{T}}$, B. arenosi DSM $16319^{\mathrm{T}}$ and B. neidei NRRL $\mathrm{BD}-87^{\mathrm{T}}$ developed the green pigment
(Supplementary Fig. S3), while strain B. pycnus NRRL NRS$1691^{\mathrm{T}}$ did not. The green colour was similar for all strains that developed the green pigment, although the pigment for B. arenosi DSM $16319^{\mathrm{T}}$ was a lighter green. For all strains, after $48 \mathrm{~h}$ of growth on R2A, over $95 \%$ of the endospores had been released from the mother cells as free spores.

The cellular fatty acid profile was determined by growing the strains on TSBA (Difco) at $23{ }^{\circ} \mathrm{C}$ for 21 and $30 \mathrm{~h}$. Analysis was performed at two time points in order to minimize the effect of sporulation on the fatty acid profile, while the incubation temperature reflects the psychrotolerant nature of the strains. After growth, bacteria were saponified and the liberated fatty acids were methylated and analysed by capillary GLC (Hewlett Packard 6890) by the Sherlock system (MIDI 4.5), according to the manufacturer's instructions. No significant differences in the fatty acid profiles were observed in relation to the different incubation times. When compared to B. arvi DSM $16317^{\mathrm{T}}$ and to each other, strains 433-D9, 121-X1 and 433E17 showed similar fatty acid profiles, supporting their affiliation to a single species. B. neidei NRRL BD- $87^{\mathrm{T}}$ exhibited a profile that did not allow differentiation from the former group, whereas B. arenosi DSM $16319^{\mathrm{T}}$ differed from this group only in a slightly lower content of anteiso$\mathrm{C}_{15: 0}$ and higher content of $\mathrm{C}_{16: 1} \omega 11 c$. B. pycnus NRRL NRS- $1691^{\mathrm{T}}$ could be distinguished from the other strains based on significant differences in the content of iso- $\mathrm{C}_{14: 0}$, iso- $\mathrm{C}_{15: 0}$, iso- $\mathrm{C}_{17: 1} \omega 10 c$ and iso- $\mathrm{C}_{17: 1} \mathrm{I} /$ anteiso- $\mathrm{C}_{17: 1} \mathrm{~B}$ and the lack of $\mathrm{C}_{15: 0}$, which is in agreement with its more distant relatedness to the other species. Once more, our results confirmed the common knowledge that fatty acid data should be only compared when highly standardized conditions for growth of biomass are applied. In comparison with data reported by Nakamura (2000) and Nakamura et al. (2002), examination of our results (Table 2) indicated some significant differences for $B$. neidei and $B$. pycnus in respect to the relative amounts of iso- $\mathrm{C}_{14: 0}$, iso- $\mathrm{C}_{15: 0}$, iso- $\mathrm{C}_{16: 0}$ and $\mathrm{C}_{16: 0} \omega 11 \mathrm{c}$ and the presence/absence of other fatty acids (B. neidei) and relative amounts of $\mathrm{C}_{16: 1} \omega 7 c \mathrm{c}$ alcohol and the presence/absence of other acids (B. pycnus). Our results from fatty acid analyses of B. arvi DSM $16317^{\mathrm{T}}$ and B. arenosi DSM $16319^{\mathrm{T}}$ also differed from corresponding strains examined by Heyrman et al. (2005). Compared with reported results, B. arvi DSM $16317^{\mathrm{T}}$ contained significantly lower contents of iso- $\mathrm{C}_{14: 0}$, $\mathrm{C}_{16: 1} \omega 7 c$ alcohol and iso- $\mathrm{C}_{16: 0}$ and higher contents of iso$\mathrm{C}_{15: 0}$, iso- $\mathrm{C}_{17: 1} \omega 10 c$ and iso- $\mathrm{C}_{17: 1} \mathrm{I} /$ anteiso- $\mathrm{C}_{17: 1} \mathrm{~B}$ and $\mathrm{B}$. arenosi DSM $16319^{\mathrm{T}}$ contained smaller amounts of iso$\mathrm{C}_{14: 0}$ and iso- $\mathrm{C}_{16: 0}$ and larger amounts of iso- $\mathrm{C}_{15: 0}$. The differences might be caused by different cultivation conditions. This study used TSBA, an incubation temperature of $23{ }^{\circ} \mathrm{C}$ and incubation times of 21 and $30 \mathrm{~h}$, while the previously published studies used TSA, an incubation temperature of $30{ }^{\circ} \mathrm{C}$ and incubation times of $24-48 \mathrm{~h}$ (Nakamura et al., 2002; Heyrman et al., 2005).

Respiratory lipoquinones and polar lipids were extracted and analysed as reported previously (Tindall, 1990a, b; 
Table 2. Cellular fatty acid profiles of strains 433-D9, 433-E17 and $121-\mathrm{X} 1$ and the type strains of $B$. neidei, B. arvi, B. arenosi and B. pycnus

Strains: 1, 121-X1; 2, 433-E17; 3, 433-D9; 4, B. neidei NRRL BD-87 ${ }^{\mathrm{T}}$; 5, B. arvi DSM $16317^{\mathrm{T}}$; 6, B. arenosi DSM 16319 ${ }^{\mathrm{T}}$; 7, B. pycnus NRRL NRS$1691^{\mathrm{T}}$. Strains were grown on TSBA at $23{ }^{\circ} \mathrm{C}$ for 21 or $30 \mathrm{~h}$ as indicated. -, Not detected.

\begin{tabular}{|c|c|c|c|c|c|c|c|c|c|c|c|c|c|c|}
\hline \multirow[t]{2}{*}{ Fatty acid } & \multicolumn{2}{|c|}{1} & \multicolumn{2}{|c|}{2} & \multicolumn{2}{|c|}{3} & \multicolumn{2}{|c|}{4} & \multicolumn{2}{|c|}{5} & \multicolumn{2}{|c|}{6} & \multicolumn{2}{|c|}{7} \\
\hline & $21 \mathrm{~h}$ & $30 \mathrm{~h}$ & $21 \mathrm{~h}$ & $30 \mathrm{~h}$ & $21 \mathrm{~h}$ & $30 \mathrm{~h}$ & $21 \mathrm{~h}$ & $30 \mathrm{~h}$ & $21 \mathrm{~h}$ & $30 \mathrm{~h}$ & $21 \mathrm{~h}$ & $30 \mathrm{~h}$ & $21 \mathrm{~h}$ & $30 \mathrm{~h}$ \\
\hline $\mathrm{C}_{14: 0}$ & - & 0.7 & 0.9 & 0.6 & 0.6 & - & 1.0 & 1.0 & 0.8 & 0.8 & 1.6 & 1.0 & - & 0.4 \\
\hline $\mathrm{i}-\mathrm{C}_{15: 0}$ & 47.0 & 46.8 & 53.7 & 53.6 & 54.9 & 57.4 & 52.4 & 54.7 & 44.7 & 46.2 & 55.2 & 55.5 & 74.3 & 74.2 \\
\hline ai- $C_{15: 0}$ & 21.9 & 21.4 & 17.1 & 16.3 & 15.5 & 15.2 & 15.4 & 15.3 & 21.6 & 21.7 & 11.3 & 11.2 & 10.0 & 9.9 \\
\hline $\mathrm{i}-\mathrm{C}_{16: 0}$ & - & 0.6 & - & 0.6 & 0.6 & - & 0.8 & 0.7 & 0.9 & 0.8 & - & 0.7 & 2.1 & 2.1 \\
\hline $\mathrm{C}_{16: 1} \omega 11 c$ & 3.6 & 3.5 & 4.0 & 3.3 & 2.9 & 2.9 & 4.1 & 3.8 & 3.8 & 3.9 & 8.2 & 7.0 & 0.7 & 0.6 \\
\hline $\mathrm{i}-\mathrm{C}_{17: 1} \omega 10 c$ & 6.3 & 5.7 & 6.6 & 7.6 & 6.2 & 7.0 & 7.0 & 6.8 & 5.4 & 5.2 & 7.0 & 7.1 & 0.8 & 0.8 \\
\hline $\mathrm{i}-\mathrm{C}_{17: 1} \mathrm{I} / \mathrm{ai}-\mathrm{C}_{17: 1} \mathrm{~B}$ & 7.7 & 7.8 & 6.2 & 7.2 & 5.3 & 5.6 & 6.3 & 5.8 & 7.2 & 6.8 & 5.1 & 5.1 & 0.7 & 0.6 \\
\hline $\mathrm{i}-\mathrm{C}_{17: 0}$ & 2.1 & 2.0 & 1.9 & 2.2 & 2.0 & 2.5 & 1.6 & 1.7 & 2.0 & 2.0 & 2.3 & 2.5 & 2.3 & 2.1 \\
\hline
\end{tabular}

Altenburger et al., 1996). The primary isoprenoid quinones present in strains B. arvi DSM $16317^{\mathrm{T}}$, B. arenosi DSM $16319^{\mathrm{T}}$, B. neidei NRRL BD-87 ${ }^{\mathrm{T}}, 433-\mathrm{D} 9,433-\mathrm{E} 17$ and $121-$ $\mathrm{X} 1$ were menaquinone MK-8 (69-81\%), menaquinone MK-7 (19-30\%) and traces of menaquinone MK-6. In contrast, B. pycnus NRRL NRS-1691 ${ }^{\mathrm{T}}$ exhibited a quinone system with the predominant compound menaquinone MK-7 (>99\%) and only traces of MK-8. Quinone systems with the predominant compound MK-8 have been reported only rarely among bacilli and representatives of Bacillus group 2, and the type species of the genus Bacillus, B. subtilis, contains a quinone system with menaquinone MK-7 predominant (Collins \& Jones, 1981). Polar lipid profiles of strains 433-D9, 433-E17, 121-X1, B. arvi DSM $16317^{\mathrm{T}}$ (Fig. 2), B. arenosi DSM $16319^{\mathrm{T}}$ and $B$. neidei NRRL $\mathrm{BD}-87^{\mathrm{T}}$ were nearly identical, exhibiting the major compounds diphosphatidylglycerol, phosphatidylglycerol and phosphatidylethanolamine, major to moderate amounts of an unknown aminophospholipid (APL1) and moderate to minor amounts of two phospholipids (PL1, PL2) and four unknown polar lipids (L1-L4). B. pycnus NRRL NRS-1691 ${ }^{\mathrm{T}}$ differed from this group by the presence of moderate amounts of an unknown phospholipid (PL3) and minor amounts of another unknown phospholipid (PL4), traces of another aminophospholipid and the lack of unknown phospholipid PL1 and aminophospholipid APL1 (results not shown). The type strains of Kurthia gibsonii and Kurthia zopfii, which were also analysed, also exhibited these major characteristics, but the relative proportion of phosphatidylethanolamine was significantly higher than in the other strains, whereas no additional aminophospholipids could be detected. This polar lipid profile lacking any glycolipid also distinguishes the group of strains analysed here from B. subtilis DSM $36^{\mathrm{T}}$. Another distinguishing trait is the presence of another aminophospholipid in B. subtilis DSM $36^{\mathrm{T}}$ (Kämpfer et al., 2006).
Analyses of peptidoglycan structures were carried out as described by Groth et al. (1996). Cell-wall peptidoglycan of strains 433-D9, B. arvi DSM $16317^{\mathrm{T}}$ and B. arenosi DSM $16319^{\mathrm{T}}$ was determined to be of the A4 $\alpha$ type with L-Lys-DAsp as described by Schleifer \& Kandler (1972), which corresponds to type A11.31 (http://www.dsmz.de/species/ murein.htm), which is also characteristic of species of the closely related genus Kurthia (Shaw \& Keddie, 1983). This

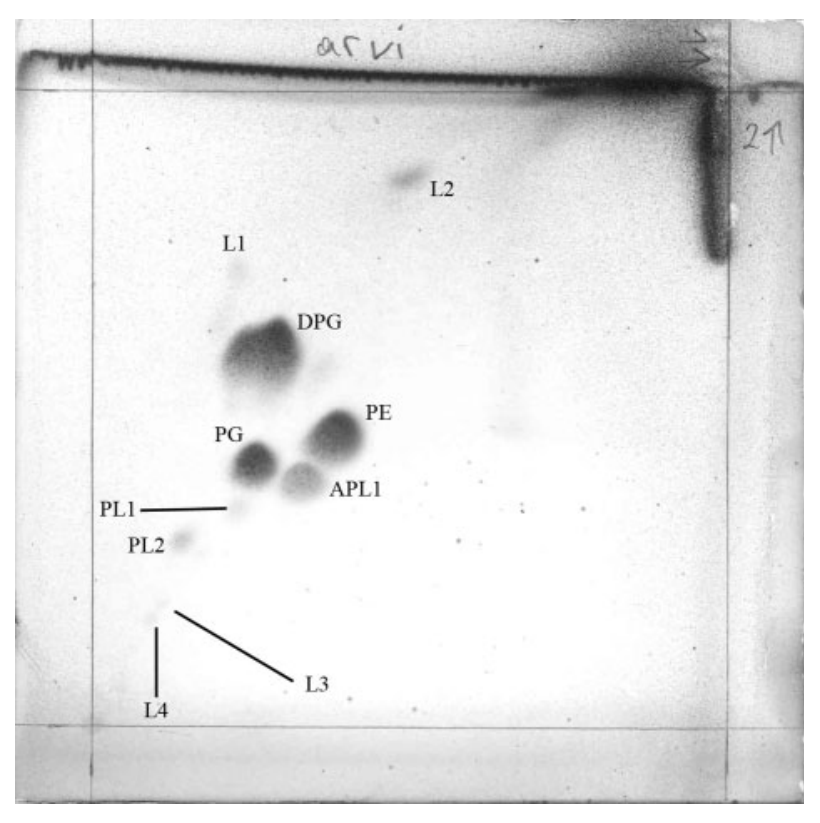

Fig. 2. Two-dimensional TLC of polar lipids of $B$. arvi DSM $16317^{\top}$. DPG, Diphosphatidylglycerol; PG, phosphatidylglycerol; $\mathrm{PE}$, phosphatidylethanolamine; PL1-2, unknown phospholipids; APL1, unknown aminophospholipid; L1-4, unknown polar lipids. 
trait distinguishes the three strains from $B$. neidei NRRL BD $-87^{\mathrm{T}}$ and B. pycnus NRRL NRS- $1691^{\mathrm{T}}$, which were reported to contain a peptidoglycan based on L-Lys-D-Glu (type A11.33).

The $\mathrm{G}+\mathrm{C}$ content was determined as described previously (Albert et al., 2005). Results of the analysis found that the $\mathrm{G}+\mathrm{C}$ content for strain $433-\mathrm{D} 9$ was $40.4 \mathrm{~mol} \%$, while that for strain $121-\mathrm{X} 1$ was $39.2 \mathrm{~mol} \%$. The $\mathrm{G}+\mathrm{C}$ contents for B. arvi DSM $16317^{\mathrm{T}}$, B. arenosi DSM $16319^{\mathrm{T}}$, B. neidei NRRL BD $-87^{\mathrm{T}}$ and $B$. pycnus NRRL NRS- $1691^{\mathrm{T}}$ were reported to be $35 \mathrm{~mol} \%$ (Nakamura et al., 2002; Heyrman et al., 2005).

It is evident from the highly similar phenotype (biochemical and physiological traits, quinone system, polar lipids, peptidoglycan type, fatty acid profile), similar genomic fingerprints and DNA-DNA hybridizations that our isolates 433-D9, 433-E17 and 121-X1 are members of the species $B$. arvi. The species $B$. arvi, B. arenosi and $B$. neidei exhibit an extraordinarily high degree of similarity in respect to their fatty acid profiles, quinone systems and polar lipid profiles and also share the peptidoglycan type A4 $\alpha$, based on the characteristic diamino acid L-lysine in their peptidoglycan, and the combination of these traits distinguishes them from related taxa of Bacillus group 2 (Ash et al., 1991) as well as from the type species of the genus Bacillus, B. subtilis (Table 3). Although the presence of D-glutamic acid in the interpeptide bridge of the peptidoglycan of $B$. neidei distinguishes it from $B$. arvi and $B$. arenosi, which were shown to contain aspartic acid in the interpeptide bridge, it appears to be justified to assign the three species to a single genus. Variations in the peptidoglycan interpeptide bridge have also been reported among certain species of the neighbouring genera Sporosarcina and Planomicrobium (Yoon et al., 2001a, b; Reddy et al., 2003), indicating that this trait can be less conserved than other chemotaxonomic traits. We refrain from assignment of $B$. pycnus to the same novel genus because it is distinguished by its phylogenetic position, quinone system, polar lipid composition and significantly smaller amounts of $\mathrm{i}-\mathrm{C}_{17: 1} \mathrm{I} / \mathrm{ai}-\mathrm{C}_{17: 1} \mathrm{~B}$ and $\mathrm{i}-\mathrm{C}_{17: 0}$ in its fatty acid profile. These data suggest that $B$. pycnus is a representative of another novel genus. However, we do not propose a novel genus for this species here because we think this should await substantiation of the characteristic traits by examination of additional closely related species. It is therefore proposed that the species Bacillus arvi, Bacillus arenosi and Bacillus neidei are assigned to the novel genus Viridibacillus gen. nov. as Viridibacillus arvi comb. nov. (the type species), Viridibacillus arenosi comb. nov. and Viridibacillus neidei comb. nov.

\section{Description of Viridibacillus gen. nov.}

Viridibacillus (Vi.ri.di.ba.cil'lus. L. adj. viridis green; L. masc. n. bacillus rod: N.L. masc. n. Viridibacillus the green bacillus/rod).

Gram-positive, spore-forming, motile rods. Endospores are round and are located terminally in a swollen or slightly swollen sporangium. Growth occurs below $10{ }^{\circ} \mathrm{C}$ and in

Table 3. Characteristics that distinguish the genus Viridibacillus gen. nov. from related taxa and the type species of genus Bacillus, B. subtilis

Data were obtained as follows: Viridibacillus gen. nov., this study; B. pycnus, this study and Nakamura et al. (2002); Kurthia, Shaw \& Keddie (1983); Lysinibacillus, Ahmed et al. (2007); Bacillus sylvestris, Rheims et al. (1999); Sporosarcina, Ranft \& Kandler (1970), Hess et al. (1979), Fahmy et al. (1985), Stackebrandt et al. (1987), Claus \& Fritze (1989), Rheims et al. (1999), Yoon et al. (2001a) and Reddy et al. (2003); B. subtilis, Kämpfer (1994), Kämpfer et al. (2006) and Claus \& Berkeley (1986). Dap, Diaminopimelic acid.

\begin{tabular}{|c|c|c|c|c|c|c|c|}
\hline Characteristic & Viridibacillus & B. pycnus & Kurthia & Lysinibacillus & B. sylvestris & Sporosarcina & B. subtilis \\
\hline Spore formation & Present & Present & Absent & Present & Present & Present & Present \\
\hline Peptidoglycan & $\begin{array}{l}\text { L-Lys-D-Glu or } \\
\text { L-Lys-D-Asp }\end{array}$ & L-Lys-D-Glu & L-Lys-D-Asp & Lys-Asp & L-Lys-D-Glu & $\begin{array}{l}\text { L-Lys-L-Ala-D-Asp } \\
\text { or L-Lys-Gly-D-Glu } \\
\text { or L-Lys-D-Glu }\end{array}$ & $\begin{array}{c}\text { meso-Dap } \\
\text { direct }\end{array}$ \\
\hline Quinone system & MK-8, MK-7 & MK-7 & MK-7 & MK-7 & MK-7 & MK-7 & MK-7 \\
\hline Polar lipids* & $\begin{array}{c}\text { DPG, PE, PG } \\
\text { APL, 2PL }\end{array}$ & $\begin{array}{c}\text { DPG, PE, PG, } \\
\text { APL, 2PL, AL }\end{array}$ & $\begin{array}{c}\text { DPG, PE, } \\
\text { PG }\end{array}$ & $\begin{array}{c}\text { DPG, PG, } \\
\text { APGL }\end{array}$ & $\begin{array}{c}\text { PG, DPG, PE, } \\
\text { PS, PL }\end{array}$ & Unknown & $\begin{array}{c}\text { PG, DPG, PE, } \\
\text { GBG, APL }\end{array}$ \\
\hline $\begin{array}{l}\text { Major fatty } \\
\text { acids } \\
(>10 \%) \dagger\end{array}$ & i-C $C_{15: 0},\left(a i-C_{15: 0}\right)$ & i- $C_{15: 0}$, ai $-C_{15: 0}$ & $\begin{array}{l}\mathrm{i}-\mathrm{C}_{15: 0} \\
\text { ai- } \mathrm{C}_{15: 0}\end{array}$ & $\begin{array}{c}\text { i- } \mathrm{C}_{15: 0},\left(\text { ai }-\mathrm{C}_{15: 0}\right. \\
\text { i- } \mathrm{C}_{16: 0}, \text { ai- }-\mathrm{C}_{17: 0} \\
\mathrm{C}_{16: 1} \omega 7 c \\
\text { alcohol })\end{array}$ & $\begin{array}{c}\text { iso- } \mathrm{C}_{15: 1} \\
\mathrm{i}-\mathrm{C}_{16: 1}\end{array}$ & $\begin{array}{c}\text { ai-C } C_{15: 0},\left(i-C_{16: 1}\right), \\
\left(\text { ai- }_{17: 0}, i-C_{14: 0},\right. \\
\text { i- } C_{17: 1} \text { I/ai- } C_{17: 1} \text { B) }\end{array}$ & $\begin{array}{c}\text { ai- } C_{15: 0} \\
\text { i- } C_{15: 0} \\
\text { ai- } C_{17: 1}\end{array}$ \\
\hline
\end{tabular}

${ }^{*}$ Major compounds are in bold. DPG, Diphosphatidylglycerol; PG, phosphatidylglycerol; PE, phosphatidylethanolamine; APL, unknown aminophospholipid; PL, unknown phospholipid; AL, unknown aminolipid; GBG, gentiobiosyldiacylglycerol; APGL, unknown aminophosphoglycolipid.

$\dagger$ Components making up $>20 \%$ of the total fatty acids are in bold. Components listed in parentheses are present at the indicated level $(>10$ or $>20 \%$ ) in some members of the taxon. 
the presence of $2 \% \mathrm{NaCl}$ but not at $7 \% \mathrm{NaCl}(\mathrm{w} / \mathrm{w})$. Sporulation and release of endospores (free spores) are abundant on R2A agar after 24 and $48 \mathrm{~h}$, respectively, at $25{ }^{\circ} \mathrm{C}$. On R2A, all members of the genus develop a green pigment. The quinone system consists of the major compound MK-8 (69-81\%) and moderate amounts of MK-7 (19-30.5\%). In the fatty acid profile, the major fatty acids are iso- $\mathrm{C}_{15: 0}$ (approx. 40-60\%), anteiso- $\mathrm{C}_{15: 0}$ (approx. 10-25\%), iso- $\mathrm{C}_{17: 1} \omega 10 c$ (approx. 5-8\%) and iso- $\mathrm{C}_{17: 1} \mathrm{I} /$ anteiso- $\mathrm{C}_{17: 1} \mathrm{~B}$. The polar lipid profile consists of the major compounds diphosphatidylglycerol, phosphatidylglycerol and phosphatidylethanolamine and major to moderate amounts of an unknown aminophospholipid (APL1) and moderate to minor amounts of two unknown phospholipids (PL1, PL2) and three unknown polar lipids. Cell wall peptidoglycan is A4 $\alpha$, either L-Lys-D-Glu or LLys-D-Asp type. The G $+\mathrm{C}$ content of genomic DNA of species of the genus ranges from 35 to $40.4 \mathrm{~mol} \%$. The type species is Viridibacillus arvi.

\section{Description of Viridibacillus arvi (Heyrman et al. 2005) comb. nov.}

Viridibacillus arvi ( $\mathrm{r}^{\prime}$ vi. L. gen. n. arvi of a field).

Basonym: Bacillus arvi Heyrman et al. 2005.

In addition to the characteristics of $B$. arvi summarized by Heyrman et al. (2005), the species exhibits the traits listed in the genus description. The previous description (Heyrman et al., 2005) is emended with data for strains 433-D9, 121-X1 and 433-E17 and the data generated as a result of this study. All strains, including the type strain, share the following attributes. Cells are straight, roundended and Gram-positive to Gram-variable, occurring singly and in pairs. On PCA, colonies are shiny, opaque, irregular and flat with a lobate edge and range from $3 \times 5$ to $6 \times 6 \mathrm{~mm}$ in size when grown at $25^{\circ} \mathrm{C}$ for $48 \mathrm{~h}$. On PCA, strains 433-D9, 121-X1 and 433-E17 develop a green pigment in $48-72 \mathrm{~h}$ of growth at $25{ }^{\circ} \mathrm{C}$, while the type strain does not. Growth occurs at 5 and $40{ }^{\circ} \mathrm{C}$. Gelatin is liquefied, while starch is not hydrolysed. Strains grow at $2 \%(\mathrm{w} / \mathrm{w}) \mathrm{NaCl}$ but not at $5 \%$. Catalase-positive and oxidase-negative. Acid is not produced from D-glucose, Dmannitol, D-xylose, D-lactose, glycerol, sucrose, D-ribose, D-mannose, D-galactose, L-arabinose or D-cellobiose. Acid is produced from fructose. Cell wall peptidoglycan is of the L-Lys-D-Asp type.

The type strain, DSM $16317^{\mathrm{T}}\left(=\mathrm{LMG} 22165^{\mathrm{T}}\right)$, was isolated from soil. Three other strains, 433-D9 (=DSM 16704 $=\mathrm{NRRL}$ B-23969), 121-X1 and 433-E17, were isolated from organic-matter-rich samples in Wisconsin, USA.

\section{Description of Viridibacillus arenosi (Heyrman et al. 2005) comb. nov.}

Viridibacillus arenosi (a.re.no'si. L. gen. n. arenosi of a sandy place).
Basonym: Bacillus arenosi Heyrman et al. 2005.

In addition to the characteristics of $B$. arenosi summarized by Heyrman et al. (2005), the species exhibits the traits listed in the genus description. Cell wall peptidoglycan is of the L-Lys-D-Asp type. The type strain is DSM $16319^{\mathrm{T}}$ $=$ LMG $22166^{\mathrm{T}}$.

\section{Description of Viridibacillus neidei (Nakamura et al. 2002) comb. nov.}

Viridibacillus neidei (nei'de.i. N.L. gen. n. neidei of Neide, in recognition of the early microbiologist E. Neide).

Basonym: Bacillus neidei Nakamura et al. 2002.

In addition to the characteristics of $B$. neidei summarized by Nakamura et al. (2002), the species exhibits the traits listed in the genus description. The type strain is DSM $15031^{\mathrm{T}}=$ NRRL BD- $87^{\mathrm{T}}=$ JCM $11077^{\mathrm{T}}$.

\section{Acknowledgements}

We would like to acknowledge the excellent technical assistance of Jerri Woodards. 16S rRNA gene sequencing of strain 433-D9 was performed by Accugenix (Newark, DE). Photomicrographs were taken with the assistance of the Electron Microscopic Laboratory at UW-Milwaukee Department of Biological Sciences.

\section{References}

Ahmed, I., Yokota, A., Yamazoe, A. \& Fujiwara, T. (2007). Proposal of Lysinibacillus boronitolerans gen. nov., sp. nov., and transfer of Bacillus fusiformis to Lysinibacillus fusiformis comb. nov. and Bacillus sphaericus to Lysinibacillus sphaericus comb. nov. Int J Syst Evol Microbiol 57, 1117-1125.

Albert, R. A., Archambault, J., Rosselló-Mora, R., Tindall, B. J. \& Matheny, M. (2005). Bacillus acidicola sp. nov., a novel mesophilic, acidophilic species isolated from acidic Sphagnum peat bogs in Wisconsin. Int J Syst Evol Microbiol 55, 2125-2130.

Altenburger, P., Kämpfer, P., Makristathis, A., Lubitz, W. \& Busse, H.-J. (1996). Classification of bacteria isolated from a medieval wall painting. J Biotechnol 47, 39-52.

Ash, C., Farrow, J. A. E., Wallbanks, S. \& Collins, M. D. (1991). Phylogenetic heterogeneity of the genus Bacillus revealed by comparative analysis of small subunit-ribosomal RNA sequences. Lett Appl Microbiol 13, 202-206.

Ash, C., Priest, F. G. \& Collins, M. D. (1993). Molecular identification of rRNA group 3 bacilli (Ash, Farrow, Wallbanks and Collins) using a PCR probe test. Antonie van Leeuwenhoek 64, 253-260.

Claus, D. \& Berkeley, R. C. W. (1986). Genus Bacillus Cohn 1872. In Bergey's Manual of Systematic Bacteriology, vol. 2, pp. 1105-1140. Edited by P. H. A. Sneath, N. S. Mair, M. E. Sharpe \& J. G. Holt. Baltimore: Williams \& Wilkins.

Claus, D. \& Fritze, D. (1989). Taxonomy of Bacillus. In Bacillus (Biotechnology Handbooks vol. 2), pp. 5-26. Edited by C. R. Harwood. New York: Plenum.

Collins, M. D. \& Jones, D. (1981). Distribution of isoprenoid quinone structural types in bacteria and their taxonomic implications. Microbiol Rev 45, 316-354. 
Fahmy, F., Flossdorf, J. \& Claus, D. (1985). The DNA base composition of the type strains of the genus Bacillus. Syst Appl Microbiol 6, 60-65.

Farrow, J. A. E., Wallbanks, S. \& Collins, M. D. (1994). Phylogenetic interrelationships of round-spore-forming bacilli containing cell walls based on lysine and the non-spore-forming genera Caryophanon, Exiguobacterium, Kurthia, and Planococcus. Int J Syst Bacteriol 44, 74-82.

Fortina, M. G., Pukall, R., Schumann, P., Mora, D., Parini, C., Manachini, P. L. \& Stackebrandt, E. (2001). Ureibacillus gen. nov., a new genus to accommodate Bacillus thermosphaericus (Andersson et al. 1995), emendation of Ureibacillus thermosphaericus and description of Ureibacillus terrenus sp. nov. Int J Syst Evol Microbiol 51, 447-455.

Gordon, R. E., Haynes, W. C. \& Pang, C. H.-N. (1973). The Genus Bacillus. US Department of Agriculture Handbook no. 427. Washington, DC: Agricultural Research Service.

Groth, I., Schumann, P., Weiss, N., Martin, K. \& Rainey, F. A. (1996). Agrococcus jenensis gen. nov., sp. nov., a new genus of actinomycetes with diaminobutyric acid in the cell wall. Int J Syst Bacteriol 46, 234-239.

Hess, A., Hollander, R. \& Mannheim, W. (1979). Lipoquinones of some spore-forming rods, lactic acid bacteria and actinomycetes. J Gen Microbiol 115, 247-252.

Heyndrickx, M., Lebbe, L., Kersters, K., De Vos, P., Forsyth, G. \& Logan, N. A. (1998). Virgibacillus: a new genus to accommodate Bacillus pantothenticus (Proom and Knight 1950). Emended description of Virgibacillus pantothenticus. Int J Syst Bacteriol 48, 99-106.

Heyrman, J., Rodríguez-Diaz, M., Devos, J., Felske, A., Logan, N. A. \& De Vos, P. (2005). Bacillus arenosi sp. nov., Bacillus arvi sp. nov. and Bacillus humi sp. nov., isolated from soil. Int J Syst Evol Microbiol 55, 111-117.

Ishikawa, M., Ishizaki, S., Yamamoto, Y. \& Yamasato, K. (2002). Paraliobacillus ryukyuensis gen. nov., sp. nov., a new Gram-positive, slightly halophilic, extremely halotolerant, facultative anaerobe isolated from a decomposing marine alga. J Gen Appl Microbiol 48, 269-279.

Kämpfer, P. (1994). Limits and possibilities of total fatty acid analysis for classification and identification of Bacillus species. Syst Appl Microbiol 17, 86-98.

Kämpfer, P., Rosselló-Mora, R., Falsen, E., Busse, H.-J. \& Tindall, B. J. (2006). Cohnella thermotolerans gen. nov., sp. nov., and classification of 'Paenibacillus hongkongensis' as Cohnella hongkongensis sp. nov. Int J Syst Evol Microbiol 56, 781-786.

Lu, J., Nogi, Y. \& Takami, H. (2001). Oceanobacillus iheyensis gen. nov., sp. nov., a deep-sea extremely halotolerant and alkaliphilic species isolated from a depth of $1050 \mathrm{~m}$ on Iheya Ridge. FEMS Microbiol Lett 205, 291-297.

Ludwig, W., Strunk, O., Westram, R., Richter, L., Meier, H., Yadhukumar, Buchner, A., Lai, T., Steppi, S. \& other authors (2004). ARB: a software environment for sequence data. Nucleic Acids Res 32, 1363-1371.

Nakamura, L. K. (2000). Phylogeny of Bacillus sphaericus-like organisms. Int J Syst Evol Microbiol 50, 1715-1722.

Nakamura, L. K., Shida, O., Takagi, H. \& Komagata, K. (2002). Bacillus pycnus sp. nov., and Bacillus neidei sp. nov., round-spored bacteria from soil. Int J Syst Evol Microbiol 52, 501-505.

Nakamura, K., Haruta, S., Ueno, S., Ishii, M., Yokota, A. \& Igarashi, Y. (2004). Cerasibacillus quisquiliarum gen. nov., sp. nov., isolated from a semi-continuous decomposing system of kitchen refuse. Int J Syst Evol Microbiol 54, 1063-1069.

Nazina, T. N., Tourova, T. P., Poltaeraus, A. B., Novikova, E. V., Grigoryan, A. A., Ivanova, A. E., Lyseko, A. M., Petrnyaka, V. V., Osipov, G. A. \& other authors (2001). Taxonomic study of aerobic thermophilic bacilli: descriptions of Geobacillus subterraneus gen. nov., sp. nov. and Geobacillus uzenensis sp. nov. from petroleum reservoirs and transfer of Bacillus stearothermophilus, Bacillus thermocatenulatus, Bacillus thermoleovorans, Bacillus kaustophilus, Bacillus thermoglucosidasius and Bacillus thermodenitrificans to Geobacillus as the new combinations G. stearothermophilus, G. thermocatenulatus, G. thermoleovorans, G. kaustophilus, G. thermoglucosidasius and G. thermodenitrificans. Int J Syst Evol Microbiol 51, 433-446.

Pearson, W. R. \& Lipman, D. J. (1988). Improved tools for biological sequence comparison. Proc Natl Acad Sci U S A 85, 2444-2448.

Ranft, H. \& Kandler, O. (1970). D-Aspartyl-L-alanin als Interpeptidbrücke im Murein von Bacillus pasteurii Migula. $Z$ Naturforsch [C] 28, 4-8 (in German).

Reddy, G. S. N., Matsumoto, G. I. \& Shivaji, S. (2003). Sporosarcina macmurdoensis sp. nov., from a cyanobacterial mat sample from a pond in the McMurdo Dry Valleys, Antarctica. Int J Syst Evol Microbiol 53, 1363-1367.

Rheims, H., Frühling, A., Schumann, P., Rohde, M. \& Stackebrandt, E. (1999). Bacillus silvestris sp. nov., a new member of the genus Bacillus that contains lysine in its cell wall. Int J Syst Bacteriol 49, 795-802.

Schleifer, K. H. \& Kandler, O. (1972). Peptidoglycan types of bacterial cell walls and their taxonomic implications. Bacteriol Rev 36, 407-477.

Schlesner, H., Lawson, P. A., Collins, M. D., Weiss, N., Wehmeyer, U., Völker, H. \& Thomm, M. (2001). Filobacillus milensis gen. nov., sp. nov., a new halophilic spore-forming bacterium with Orn-D-Glu-type peptidoglycan. Int J Syst Evol Microbiol 51, 425-431.

Shaw, S. \& Keddie, R. M. (1983). A numerical taxonomic study of the genus Kurthia with a revised description of Kurthia zopfii and a description of Kurthia gibsonii sp. nov. Syst Appl Microbiol 4, 253-276.

Shida, O., Takagi, H., Kadowaki, K. \& Komagata, K. (1996). Proposal for two new genera, Brevibacillus gen. nov. and Aneurinibacillus gen. nov. Int J Syst Bacteriol 46, 939-946.

Smibert, R. M. \& Krieg, R. N. (1994). Phenotypic characterization. In Methods for General and Molecular Bacteriology, pp. 607-654. Edited by P. Gerhardt, R. G. E. Murray, W. A. Wood, N. R. Krieg. Washington, DC: American Society for Microbiology.

Spring, S., Ludwig, W., Marquez, M. C., Ventosa, A. \& Schleifer, K. H. (1996). Halobacillus gen. nov., with descriptions of Halobacillus litoralis sp. nov., and Halobacillus trueperi sp. nov., and transfer of Sporosarcina halophila to Halobacillus halophilus comb. nov. Int J Syst Bacteriol 46, 492-496.

Stackebrandt, E., Ludwig, W., Weizenegger, M., Dorn, S., McGill, T. J., Fox, G. E., Woese, C. R., Schubert, W. \& Schleifer, K.-H. (1987). Comparative $16 \mathrm{~S}$ rRNA oligonucleotide analyses and murein types of round-spore-forming bacilli and non-spore-forming relatives. J Gen Microbiol 133, 2523-2529.

Tindall, B. J. (1990a). A comparative study of the lipid composition of Halobacterium saccharovorum from various sources. Syst Appl Microbiol 13, 128-130.

Tindall, B. J. (1990b). Lipid composition of Halobacterium lacusprofundi. FEMS Microbiol Lett 66, 199-202.

Wainø, M., Tindall, B. J., Schumann, P. \& Ingvorsen, K. (1999). Gracilibacillus gen. nov., with description of Gracilibacillus halotolerans gen. nov., sp. nov.; transfer of Bacillus dipsosauri to Gracilibacillus dipsosauri comb. nov., and Bacillus salexigens to the genus Salibacillus gen. nov., as Salibacillus salexigens comb. nov. Int J Syst Bacteriol 49, 821-831.

Wieser, M. \& Busse, H.-J. (2000). Rapid identification of Staphylococcus epidermidis. Int J Syst Evol Microbiol 50, 1087-1093.

Wisotzkey, J. D., Jurtshuk, P., Jr, Fox, G. E., Deinhard, G. \& Poralla, K. (1992). Comparative sequence analyses on the 16S rRNA (rDNA) of 
Bacillus acidocaldarius, Bacillus acidoterrestris, and Bacillus cycloheptanicus and proposal for creation of a new genus, Alicyclobacillus gen. nov. Int J Syst Bacteriol 42, 263-269.

Yoon, J.-H., Lee, K.-C., Weiss, N., Kho, Y. H., Kang, K. H. \& Park, Y.-H. (2001a). Sporosarcina aquimarina sp. nov., a bacterium isolated from seawater in Korea, and transfer of Bacillus globisporus (Larkin and Stokes 1967), Bacillus psychrophilus (Nakamura 1984) and Bacillus pasteurii (Chester 1898) to the genus Sporosarcina as Sporosarcina globispora comb. nov., Sporosarcina psychrophila comb. nov. and Sporosarcina pasteurii comb. nov., and emended description of the genus Sporosarcina. Int J Syst Evol Microbiol 51, 1079-1086.

Yoon, J.-H., Kang, S. S., Lee, K.-C., Lee, E. S., Kho, Y. H., Kang, K. H. \& Park, Y.-H. (2001b). Planomicrobium koreense gen. nov., sp. nov., a bacterium isolated from the Korean traditional fermented seafood jeotgal, and transfer of Planococcus okeanokoites (Nakagawa et al. 1996) and Planococcus momeekinii (Junge et al. 1998) to the genus Planomicrobium. Int J Syst Evol Microbiol 51, 1511-1520.

Yoon, J.-H., Weiss, N., Lee, K.-C., Lee, I.-S., Kang, K. H. \& Park, Y.-H. (2001c). Jeotgalibacillus alimentarius gen. nov., sp. nov., a novel bacterium isolated from jeotgal with L-lysine in the cell wall, and reclassification of Bacillus marinus Rüger 1983 as Marinibacillus marinus gen. nov., comb. nov. Int J Syst Evol Microbiol 51, 2087-2093.

Ziemke, F., Höfle, M. G., Lalucat, J. \& Rosselló-Mora, R. (1998). Reclassification of Shewanella putrefaciens Owen's genomic group II as Shewanella baltica sp. nov. Int J Syst Bacteriol 48, 179-186. 